Nature Park Amager-examining the transition from urban wasteland to a rewilded ecotourism destination

Kaae, Berit C.; Holm, Jesper; Caspersen, Ole Hjorth; Gulsrud, Natalie Marie

Published in:

Journal of Ecotourism

DOI:

10.1080/14724049.2019.1601729

Publication date:

2019

Document version

Early version, also known as pre-print

Citation for published version (APA):

Kaae, B. C., Holm, J., Caspersen, O. H., \& Gulsrud, N. M. (2019). Nature Park Amager-examining the transition from urban wasteland to a rewilded ecotourism destination. Journal of Ecotourism, 18(4).

https://doi.org/10.1080/14724049.2019.1601729 


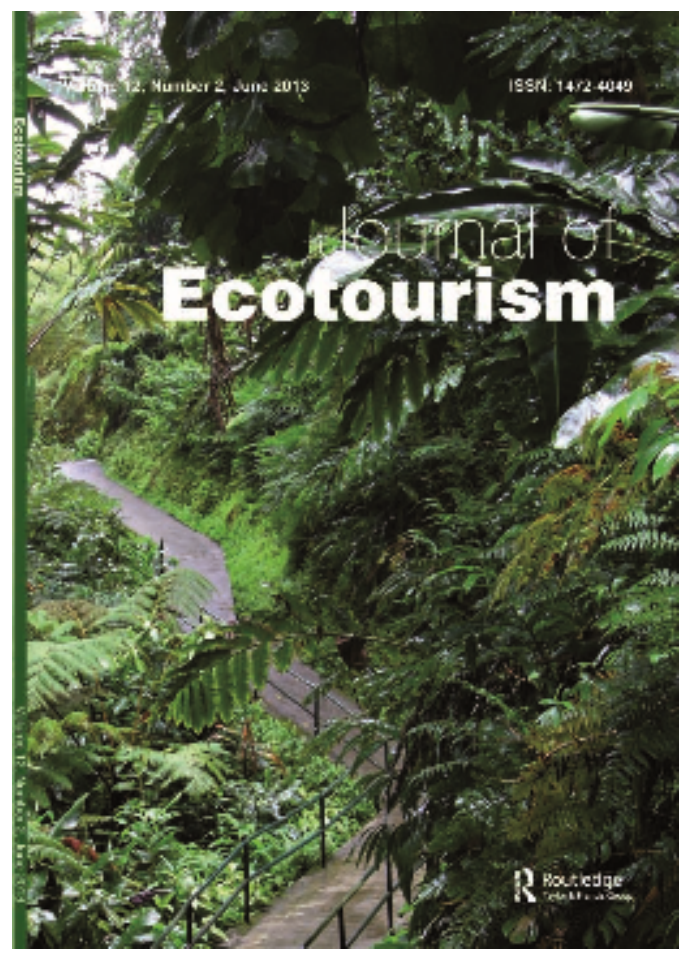

\section{Nature Park Amager - Examining the transition from urban wasteland to a rewilded ecotourism destination}

\begin{tabular}{|c|l|}
\hline Journal: & Journal of Ecotourism \\
\hline Manuscript ID & JOE-0920.R1 \\
\hline Meywords: & $\begin{array}{l}\text { natural resource management, nature-based tourism, sustainable } \\
\text { tourism, tour guides and operators, Wilderness, green consumerism }\end{array}$ \\
\hline Abstract: & $\begin{array}{l}\text { Urban ecotourism and urban rewilding may form a sustainable transition } \\
\text { path for both tourism and urban wilderness. In an explorative case } \\
\text { study, we analyse this option by reconstructing the history of an } \\
\text { extensive urban wasteland formerly used as military shooting range and } \\
\text { dumpsite and converted to a Nature Park in 2015. The transformation of } \\
\text { this urban wasteland has a long history which is shaped by changes in } \\
\text { society, technologies, and consequently in ecologies during different } \\
\text { periods reflecting prevailing paradigms of nature perceptions over time. } \\
\text { We seek to provide a theoretical frame using the social-ecological- } \\
\text { technological systems (SETs) framework and transition theory to } \\
\text { describe the transformations of the site from its pre-wasteland stage to } \\
\text { rewilding and recreation and lately niche development of urban } \\
\text { ecotourism. Results reveal that Amager Nature Park is an excellent case } \\
\text { illustrating the transformation of an urban wasteland into a nature park } \\
\text { providing recreational experiences, interpretative facilities, and guided } \\
\text { ecotourism tours for tourists. }\end{array}$ \\
\hline
\end{tabular}


Page 1 of 19

\section{SCHOLARONE ${ }^{\text {m }}$ Manuscripts}




\title{
Nature Park Amager - Examining the transition from urban wasteland to a rewilded ecotourism destination
}

\begin{abstract}
Urban ecotourism and urban rewilding may form a sustainable transition path for both tourism and urban wilderness. In an explorative case study, we analyse this option by reconstructing the history of an extensive urban wasteland formerly used as military shooting range and dumpsite and converted to a Nature Park in 2015. The transformation of this urban wasteland has a long history which is shaped by changes in society, technologies, and consequently in ecologies during different periods reflecting prevailing paradigms of nature perceptions over time. We seek to provide a theoretical frame using the social-ecological-technological systems (SETs) framework and transition theory to describe the transformations of the site from its pre-wasteland stage to rewilding and recreation and lately niche development of urban ecotourism. Results reveal that Amager Nature Park is an excellent case illustrating the transformation of an urban wasteland into a nature park providing recreational experiences, interpretative facilities, and guided ecotourism tours for tourists.
\end{abstract}

\section{Introduction}

Ecotourism has many definitions (Fennell, 2015) but can be formally defined as "responsible travel to natural areas that conserves the environment, sustains the well-being of the local people, and involves interpretation and education" (TIES, 2015). In this latest revision, education is upgraded and meant to be inclusive of both staff and guests. In essence ecotourism combines sustainable tourism with nature tourism and adds a learning experience as a key characteristic.

\section{Urban nature and rewilding}

The key role of nature conservation in ecotourism connects it to protected nature areas and hereby generally to ecosystems of high quality, long existence, and pristine wilderness character which tend to be located far from major urban areas. However, new focus has been placed on so-called "urban nature" as global trends in urbanization have increased urban populations, bringing focus to the environmental challenges and opportunities associated with dense urban living in post-industrial cityscapes. Urban nature in this context relates to postindustrial brownfields and blue-green infrastructure such as parks, street trees, and urban waterways. However, specific attention has been paid to the "spontaneous" or "accidental" progression of urban ecosystems "without deliberate human interventions" and the diverse social and ecological values related to so-called urban wilderness. Based on these criteria Kowarik and others have made the link between wilderness and post-industrial urban sites that have undergone spontaneous regeneration (Kowarik, 2013:33). Cities across the globe are therefore initiating urban rewilding campaigns by transforming former "wastelands" to postindustrial blue and green infrastructure such as expansive and uncultivated parks, urban forests and community gardens (Hall, 2013).

Urban rewilding focuses on the deliberate establishment of suitable habitats for (former) native species embedded in somewhat wilder eco-subsystems in different kinds of wastelands, abandoned places, or "drossscapes" (Berger, 2006, Liua and Pan, 2014). Spaces, species, and organic infrastructure are merged to enhance a type of ecosystem that either comes close to historical, wild, urban fringe landscapes before human intervention took over, or pragmatically may become an urban ecosystem; resilient under climate change and urban impacts, and with an internal ecosystemic succession, not cultivated. This is what may be 
perceived as wild in the Anthropocene. Species are here naturally selected by their adaptability to life in an urban area, while performing basic ecosystem services such as water distribution, nutrition provision.

What we are interested in here is how ecotourism as a trade and activity may be a relevant part and a process in urban rewilding, potentially even contributing to socio-ecological interactions. Such human-nature interactions in rewilded urban landscape are currently in focus in Fresh Kills Park in New York City. The park is a former garbage dump, which has been transitioned into a world-class 2,200 hectare large park since 2001, with an extensive trail system and recreational opportunities spanning playgrounds, to kayak facilities, and large-scale art installations. Ecotourism is playing a critical role in Fresh Kills and experts have predicted that this park could have a positive impact in terms of ecosystem protection and will attract economic investments including a boost in tourism (The Freshkills Park Alliance 2018). Other relevant examples illustrate the global and cross-cultural extent of urban re-wilding and eco-tourism development. In Soul, South Korea, The Gyeongui Line Forest Park, a previously underutilized railroad converted to a rewilded linear park, has attracted new visitors and commerce (Park and Kim, 2019). Along the former wastelands of the Berlin Wall in Germany, eco-tourism has focus on unlikely and informal urban green areas (Stoetzer, 2018) as well as formal post-industrial parks where biodiverse urban ecosystems are well visited and are flourishing (Kowarik, 2019). In these cases, postindustrial green areas are extensive and often protected to prevent urbanization and conserve the new ecosystems that have gradually established on-site. However, this emerging touristic orientation of rewilded sites rarely takes the step further of providing interpretation and education to travelers - all key characteristics of ecotourism.

When asked to imagine a typical ecotourism destination, most people will likely describe a remote wilderness largely untouched by humans (Gibson et al. 2003). This ideal of nature as separate from culture is core to the modern nature/culture dualism, which underpins much of Western thought and practice today (Braun, 2002; Gunn \& Owens 2006). The spatial manifestation of this dualism is the city viewed as the 'opposite' of nature (Kaika 2005:5). However, in recent decades increased interdisciplinary scholarship has mounted substantial critique to this ontological divide in favor of a general view of nature as social (Kaika, 2005; Braun, 2002). With geoscientists working towards the official declaration of the Anthropocene (Lewis \& Maslin 2015), this perspective is becoming operationalized and will likely play an increasingly important role in nature-based endeavors. In the last two decades socio-ecological urban studies, resilience oriented climate mitigation in urban planning, and urban greening by municipalities and ENGOs have served the background for blue-green urban development, enhanced focus on the role of brown areas, terrain vague etc. (for an overview see Hall 2013, Mell 2016).

For ecotourism ventures, a reimagining of the relation between nature and culture opens up new opportunities for tourism in, and near, cities. A literature review (Ebbesen and Holm, 2018) indicates a recent surge in academic attention to tourism in urban and peri-urban nature, which is accompanied outside of academia with growing interest from cities in sustainable tourism (Holden, 2015, Maćkiewicz \& Konecka-Szydłowska, 2017:297). Another literature review by Margaryan (2012) found: “ [...]tourism is, undoubtedly, considered an important factor for the Rewilding vision and suggested practices. Its importance is presented in two main manifestations: source of income and facilitator of environmental education and connection to nature." Among different options for business cases in rewilding, tourism is the most promising, for instance setting in large animals as a tourist attraction. According to Donlan (2005) "[....] an understanding of ecological and evolutionary history, inspired by visits to private or public reserves containing free-roaming megafauna, could strengthen 
support for conservation. Pleistocene re-wilding would probably increase the appeal and economic value of both private and public reserves, as evidenced by the restoration of wolves to Yellowstone National Park." (Donlan quoted in ibid).

While some critics may consider urban ecotourism an oxymoron (Higham \& Lück, 2002:36), most of the literature posits a positive potential for mutual benefits to the urban environment, population and economy (Timur \& Getz, 2009; Jegdić \& Gradinac, 2016). Our review has found interesting cases of guided urban ecotourism in e.g. Barcelona, Helsinki, Novo Sad, and Seattle. While many scholars acknowledge the potential for ecotourism in urban settings, Higham and Lück (2002) argue that urban settings may offer superior qualities largely unrecognizable through ecotourism definitions. The authors discuss three cases of (peri-) urban ecotourism in New Zealand: The Oamaru Little Blue Penguin Colony, Dolphin Explorer Auckland, and Karori Reservoir Wildlife reserve. All three cases take place on former industrial sites, the natural environment which the operations aim to improve. They find that urban ecotourism contributes economically to ecological restoration of previously industrialized areas, lowers transportation compared to pristine ecoturism, enhances ecolearning for newcomers, and that the financial potential for tourism is more stable in cities.

However, as an emerging field, urban ecotourism remains under-researched and examples of real-life implementation are relatively scant (Ebbesen \& Holm, 208). One factor in the underdevelopment of urban nature-based tourism seems to be the perception of 'wilder' nature as superior, yet new research comparing urban and mountain forests suggests no significant difference in measurable visitor satisfaction (Lee \& Lee, 2015). Furthermore, the rewilding of urban areas has increased attention for urban planners and citizen led projects, and research gives evidence that "urban wilderness projects in Europe demonstrate that multitargeted approaches to conserving and managing existing novel urban ecosystems offer manifold opportunities to combine biodiversity conservation and wilderness experience" (Kowarik, 2018:336). So rewilding of urban areas, postindustrial sites, or other types of 'wastelands' may become an interesting option for ecotourism and an outset for codevelopment. In this way we may unfold UN's sustainable tourism visions along the 17 SDG. On Goal 12 to 'Ensure sustainable Consumption and Production patterns' it is stated: $A$ tourism sector that adopts sustainable consumption and production (SCP) practices can play a significant role in accelerating the global shift towards sustainability (UNWTO, 2016). This sustainability orientation applies to all types of tourism but combining sustainability, with protected rewilded urban nature and an educational/interpretative perspective can accelerate both urban rewilding and ecological awareness among tourists and in the tourism sector. Rewilding urban sites and the role of urban ecotourism herein may accordingly be interesting to study in order to clarify what may be the preconditions for this development of the tourism sector to unfold positively. This includes studying experience potentials, flora and fauna preferences. Our aim with the paper, is to take an exemplary comprehensive overlook at the historical development of parks and ecotourism in Denmark. We do so by focusing our analysis on the history of Nature Park Amager.

\section{Methodology}

The article is based on former and current R\&D projects on Nature Park Amager and sustainable tourism/ecotourism R\&D projects in Denmark (Caspersen and Petersen 2015, Petersen and Caspersen 2015, Holm \& Kaae 2017, Holm et.al. 2013). Mixed methods are used: literature reviews, various site analyses based upon desk top studies of historical materials, stake-holder interviews, training programs for guides, and a PPGIS survey among park visitors. Furthermore, in our current research we have used a narrative approach to identify the locality in a culture-nature redefinition, and we have been informed by a historical review of the Danish efforts in sustainable/ecotourism interventions (Holm and 
Kaae 2017). Finally, our work takes inspiration from a combined use of social-ecologicaltechnological analysis and transition theory. The former analyzing the drivers and codependencies between human, infrastructural, and nature relations, including shifting human perceptions of nature across time (Smith and Stirling 2010, McPhearson et al. 2016). . The latter is a theoretical approach for supporting and studying change processes of regimes of practice and upcoming socio-technical systems based upon niche experimentation or management.

\section{Theoretical frame}

For our analyses of the historical transitions and rewilding processes in Nature Park Amager, we use the Social-Ecological-Technological systems (SETs) framework (McPherson et al., 2016; Depietri \& McPherson, 2017). We add a time dimension (Figure 1) to illustrate that the importance of the social-ecological-technological domains and interactions between them, have varied greatly during different times and stages of transformation of the site.

Secondly we use transition theory to study change processes over longer time spans, and especially for identification of substantial transitions in socio-technical systems (e.g. mobility, food manufacturing, tourism) (De Schutter \& Lenoble, 2010). A multi-level perspective forms an analytical concept to conceive of transitions as relating to niches, regimes, and landscapes. In so-called 'innovation journeys', structural innovations are developed in niches which then need to be up scaled to the regime level to induce a regime shift (Schot \& Geels, 2008; Geels, 2011). Transition management may spur the governance of structural changes in which a society, a region, or societal subsystem evolves towards new structural innovations (e.g. Rotmans \& Loorbach, 2009; Søndergaard et.al, 2015). Such as transition management for sustainability orientation in tourism or urban rewilding as a new development path.

Socio-technical regimes are dominant practices, standards, rules, norms, and shared assumptions that structure the behavior of private and public actors. Niches are special (local) domains where 'non-standard' solutions, practices and technologies develop. Socio-technical regimes also have ecological conditions and impacts specifically related to political norms, rules, and regulations of a specific site (Smith \& Stirling, 2010). As our focus here is on niche development of ecotourism in specific urban nature destinations under rewilding, it is important to analyze the impacts, of not only dominant social practices and technological regimes on the site, but also the related social-ecological elements and drivers of transition (Hodson \& Marvin, 2010). Urban green infrastructure, such as a rewilded urban brownfield, mediates the relationships between human activities and ecosystem processes amongst others through technical innovation, social systems, and ecosystem functions. These aspects of urban green infrastructure are inter-related and can therefore be labelled as eco-technological, sociotechnological, and socio-ecological couplings (McPhearson et.al, 2016). An eco-technological system in urban green infrastructure relates to technological advancements that efficiently contribute to the biophysical cultivation and maintenance of landscapes, ranging from engineered water management systems to the mechanized removal of grass (Gulsrud et.al, 2018). These technological applications have accompanying implications relating to how social processes shape the development, use of technology, and in turn open up new possibilities for social practices and preferences linked to institutionally structured market incentives and consumer demands (Smith \& Stirling, 2010). Socio-ecological systems of urban green infrastructure describe human relations to ecological processes, form, and services, such as place-specific human perceptions, experiences, and values of nature (Andersson et.al, 2014). Taken together these systems influence the configuration, development, and management of urban green infrastructure. 
The development of the socio-technical regimes are framed an under influence from their societal context, which is termed the socio-technical landscape. It is a combined term for the external conditions reaching from the existing, historically handed-down material structures, political and ideological agendas and social values to macroeconomic trends. Shifts in the socio-technical landscape with articulation of new demands/expectations and/or changed technical/economic conditions will put existing regimes under a pressure that will require them to adapt, either through an evolutionary transformation or through more radical transition processes. Thus, steadily increasing over tourism in European cities and climatepolitical goals in combination have changed the political-economic landscape in Denmark to such a degree, that some municipalities, tourism trades and parks have embarked on creating experiments and niche-supporting, political initiatives for slow tourism and nature tourism.

Figure 1: Social-Ecological-Technological systems (SETs) framework with a time dimension. (Inspired by Depietri \& McPherson 2017).

\section{Case area Nature Park Amager}

Our case area, Nature Park Amager is a large green area at the island of Amager just a few kilometers from the city center of Copenhagen, Denmark. Originally, Kalvebod Common and Amager Common were salty meadows next to the shallow waters that dominate the eastern coast of Amager. But landfill and reclaiming changed the coastal area significantly during the last century. The area has been used by the military since the 17 th century for practice in shooting with artillery. The military practice started at Amager Common which is the northern part of the area, and later at the much larger Southern part Kalvebod Common that was reclaimed and drained for this purpose in 1939 to1943. In 1956 the area was ready for military use, however the shooting range of the modern artillery soon became too large for the area. Hence the military moved its activities and abandoned the area, and in 1984 the ownership was transferred partly to the municipality of Copenhagen and partly to the Ministry of Environment. The area was afterwards cleared for ammunition and opened to the public. The nature values of the area continued to increase along ecological succession in the wetlands, marsh and meadows with the arrival of a number of rare species, and in 1990 a conservation act was implemented in order to protect the environmental qualities of the area. This protection further enhanced the green and recreational development in the area and secured the area as a large green recreational zone ; new blue-green wedge of Copenhagen. The plan process culminated in 2015, when the owners (Ministry of Food and Environment, the private company City and Harbor and the municipalities of Copenhagen, Tårnby, and Dragør) proposed that the 3,500 ha area should be designated as a nature park for environmental and recreational purposes. The Nature Park Amager was officially approved in 2015. The first parks plan was approved in 2017 and has a strong focus on increasing visitation and making the park more accessible through improved gateways and visitor facilities. Our writing relates to an urban ecotourism project supported by the Danish Innovation Foundation launched in 2017. We have prepared a number of analyses, the development of narratives to strengthen the identity of the site, proposed new tourist facilities, and educated a number of guides as urban ecotourism guides (the INUT project).

Figure 2a and 2b: Amager island before (1920) and after the reclamation which was initiated in 1939. When the reclamation was finished in 1943 the area of Amager was increased with nearly one third. (Sources: Geodatastyrelsen 1920 and 2014).

\section{Historical analysis of the site}


Transformations and changes take place constantly across the social, ecological, and technological domains of urban green infrastructure. As seen in table 1, Nature Park Amager can be described in four main phases: A pre-disruption phase where the site has mature ecosystems and limited human use and few influences from technological advances but pressures are mounting in particular during the early 1900s. A disruption phase where major changes occur that transform the ecosystems almost entirely. A third military phase where natural succession and rewilding are taking place and the site is fenced off from public use. Fourthly, a public recreational phase where the rewilding has reached a state of attractiveness to a number of recreation activities and is leading up to the present day emergence of ecotourism activities.

\section{Table 1: The main phases of change in the site now appointed Nature Park Amager and selected frameworks.}

\section{Phase 1 (pre-disruption)}

Transformations have shaped the site since it emerged from below the latest ice sheet approximately 12,000 years ago as part of a continuous landmass stretching from present day UK to Sweden. Rising sea levels submerged large parts of the land and caused a conversion of the Baltic Sea from a freshwater lake to brackish seawater and Amager emerged as a low island in the Øresund gateway to the Baltic Sea. Human settlement of the ecologically rich and strategically important region laid the foundation for the present day Danish capital of Copenhagen.

Applying the Social-Ecological-Technological systems (SETs) framework (figure 1) the ecological-biophysical domain dominated during this phase. Most of the present day Nature Park Amager was shallow seas and wet coastal marshlands which regularly flooded while the higher parts were commons used for livestock grazing (Friluftsrådet, 1990). Ecologically, from a present-day view, these areas held rich marine and terrestrial habitats and supported a diverse birdlife of both nesting and migratory species on the flyway to Sweden and beyond. The low-lying flood prone island was of limited interest for human activities.

However, the social behavioral domain gradually gained importance during the 1600s when Dutch farmers settled the higher parts of the island. Interactions with the ecologicalbiophysical domain and human impacts increased from the 1700-1800s as the northern part, Amager Common, became the dump-site of the overcrowded walled city of Copenhagen and a site for executions. (Even today the island is still nicknamed as the 'trash island'). Local residents used the areas for grazing and coastal fishing.

The technological-infrastructural domain started to influence a few coastal parts of the site in the 1600s as the military established a number of facilities for military exercises and for use as shooting range. Interactions between the technological and social domains increased from the mid-1800s, when industrialization started to pressure Copenhagen and resulted in urbanization beyond the walls from the 1880s also affecting the northern rim of Amager Island. New forts were established during the construction of the new fortification of Copenhagen in the early $20^{\text {th }}$ century. Also. technological-ecological interactions increased as machinery capable of dredging and deepening the Copenhagen harbor were developed. The idea was to create a SW entrance to the harbor, which could increase the use of the southern quays and at the same time convert the shallow sea along the channel to land by use of landfill and waste. However, these plans were not yet realized due to technical and economic limitations. 


\section{Phase 2 Disruption}

The technological-infrastructural domain dominates this phase. From 1939 - 1943 more than 3,000 hectares of shallow sea were converted to dry land. The military was in need of more space to enlarge their shooting range. Improved technology dictated an increase in distance from local housing areas. The technological-ecological interactions were strong with the technologies causing an almost total ecological disruption by transformation of primarily natural marine and wet terrestrial habitats into dry land. Behind the new dike, a number of straight drainage channels were dug and pumps installed to keep the water table low. Many other similar projects took place around Denmark starting in the late 1800 s in order to utilize nature areas perceived as non-productive 'wastelands' (heathlands, lakes, river valleys, fjords etc.) Nature perception was primarily a utilitarian perspective and more farmland was needed to e.g. compensate for lost lands in Southern Denmark during the 1864 war with Germany.

When the military left the inner part of Amager Common its use changed into a garbage dump for Copenhagen and additionally also as a chemical dump until 1967, when national legislation on pollution prevention was enacted. After it was closed the former dump was sealed with a $3 \mathrm{~m}$ thick layer of clay and left nearly unmanaged for more than 20 years.

The social-behavioral domain was weak but the technological transformation was undertaken as an employment project that also prevented enrollment of 400-600 Danish men in the German war industry by the occupying German WWII forces. Urban recreational activities in Copenhagen increased during the 1930s as a response to health problems (e.g. Tuberculosis) and improved labor laws providing more free time. But the construction and later military uses prevented recreational access to the site. The ecological-biophysical domain was almost completely changed and the existing habitats destroyed. Social-ecological interactions were few but a number of local fishers protested against the plan that would ruin their fishing grounds (Caspersen, 2016).

\section{Phase 3 rewilding - the military phase}

The technological-infrastructural domain predominated as the former shallow sea area was used as a military area and artillery shooting range. During the cold war, missile launches were established on site as a defense of Copenhagen from 1959 to 1981. This included a modernization of the Kongelund Fortress into a command station for the missiles (Caspersen, 2018). However, the area relatively soon became too small due to technological advances in artillery and the military interest in the site declined in the 1980 s.

The ecological-biophysical domain was in general not an important part of the new military function and the site was left for natural regeneration. All marine habitats had collapsed by the conversion to dry land while the coastal wetlands became drier and less salty as the area underwent a gradual desalination from rainfall and a natural succession of smaller vegetation began. Explosion holes created small scale wetlands in some parts. This may be described as a rewilding process in which the military did not interfere much except for regulating the ground water table. But some more protective technological-ecological interactions include that the military had a nature conservation group and already in 1952, before the completion of the site reconstruction, a 374 ha wetland in the SE part of the area was designated as conservation area, as there had been a significant increase in bird population (Forsvarsministeriet og Miljøministeriet, 1974).

Within the social-behavioral domain increased wealth in society and urbanization during the 1960s mounted pressure on the fringes of the site and hereby interactions between the socialbehavioral domain and the technological-infrastructure domain. Large parts of Amager 
Island had already become urbanized and more housing was needed. The military use of the site excluded public access. This also highly affected interaction with the ecological-

biophysical domain and during the 1960s, the northern part of Amager Common was used as a dump and chemical waste dumping continued until 1974. However, the utilitarian perceptions of nature as a resource started to change as environmental awareness of pollution increased in the 1970s. Grassroots organizations promoting nature protection, alternative energy, and demilitarization were established in society. By the 1980ies conservation groups started to take an interest in the site (Friluftsrådet, 1990). Increasing societal awareness regarding the perils of environmental degradation increased the interest of local conservation sites in the area. Thus social-behavioural actions began to positively impact on the environmental-biophysical domain. This reflects nature perceptions and perspectives on conservation as a "nature despite people" perspective on conservation (Mace, 2014). However, once a year, the military allowed public access (Caspersen, 2016).

\section{Phase 4 - the recreational phase}

The social-behavioral domain gained importance when the military left the site in the late 1980s and the public gained access to existing roads. Significantly, the public was not allowed access to, excluding the nature areas in between the roads due to danger of unexploded ammunition.

Pressure from the technological-technical domain was high as plans for urbanization and infrastructure development were prepared but mainly on the higher grounds along the eastern fringe. The majority of the site was too low-lying and wet and was designated as a nature area - again perceived as a type of 'wasteland' in relation to human utilization. The socialecological interactions changed in 1974, when the municipality of Copenhagen discontinued using the northern part of Amager Common as a dump and converted it to allotment gardens in 1979 (Caspersen 2018). The rest of area was subsequently left to a rewilding process after which (approximately 20 years later) the municipality developed a management plan. In 1990 both Kalvebod Common and most of Amager Common was protected through a conservation act.

The social-ecological interactions have gradually increased. The transformation to a public nature area and a bird sanctuary also brought the development of recreational facilities and services (e.g. different types of trails, birdwatching towers, a café, nature interpretation programs and visitor facilities). This process is ongoing; a number of local eNGOs today use the wilderness for various social empowerment projects, therapists do healing courses, chefs and lay people sow wild herbs. In 2015, the site became a Nature Park with a partnership between four municipalities and the Nature Agency and the development company By \& Havn. A park plan has been approved and management now aims at maintaining the open wet grasslands.

With around 1 million annual visits, the nature park has now become a major urban attraction in Copenhagen. It is mostly visited by locals but a new era of ecotourism is emerging. In 2017 a number of analyses were undertaken within the former described INUT project, to identify the core qualities and narratives of the nature park, as perceived by local stakeholders and the history. This resulted in a narrative of 'the land created by humans' which tells the same story of how the site has been transformed and shaped by humans into the present day landscape (Norrøn Architects, 2017). It focuses on the role of water and raising sea levels. Thus, urban rewildering is becoming a narrative and attraction. Guided ecotourism tours have been offered to tourists since 2018 . 
The nature perceptions and perspectives on conservation as a "nature for people" (Mace, 2014 ) reflects the now public access and high visitor numbers. Examples of the more recent shift towards a more two-way, dynamic interrelationship between "people and nature" (Mace, 2014) may be reflected in the increasing volunteering and participation in cow guilds etc. where citizens actively feed and care for grazing cattle on the site in order to have first rights to the meat of the cows once they are slaughtered in the fall. Stewarding a local food production exemplifies the strong socio-ecological relations in the park - likewise do guided gatherings of herbs and berries in the Nature Park. Significantly, conflicting views and motives on conservation are increasing with the number of visitors to the park. Citizens are intensely interested in the biodiversity of the park, and are actively fighting the city over plans to build housing on the fringes of the park hereby opposing further interference from the technological-infrastructure domain.

In the ecological-biophysical domain, the natural rewilding processes took place relatively undisturbed in the fenced-off military area. By the opening of the site to recreation, these new habitats were well-established and appealing to visitors hereby strengthening socialecological interactions. However, the natural succession continues with trees starting to spread - in particular Birch trees. The rewilding process is increasingly becoming managed since the Nature Agency became responsible for the site and to prevent forestation, the water table was raised and livestock grazing established. This further diversified flora and fauna. Local residents are now more integrated and can own part of the grazing cattle.

In the technological-infrastructural domain, technology changes caused the military abandonment of the site. However, technological advances also contributed directly to the large infrastructure development - a metro line, a freeway connecting Copenhagen to a new bridge to Sweden, services and office buildings in Ørestaden and extensive urbanization of approx. 10.000 citizens by 2016. Although the technological-social interlinkages have greatly changed the surrounding areas, the on-site influences have declined. The technologyecological interactions are less visible but still the foundation for the ecology of the site and focus have changed towards the climate change adaptation agenda e.g. as the dike protecting the site from the sea was increased by 2 meters in 2005-2009 as part of large scale plans to protect all of Copenhagen from rising sea levels.

\section{Discussion}

To enhance the niche formation in urban ecotourism on former wastelands, it is useful to study the development of the complex socio-techno-ecological processes of urban rewilding. Seen from a historic perspective we have found it useful to apply the SETs framework in organizing the massive changes and interactions that have shaped the site of present time Nature Park Amager. Not all aspects can be covered in a short paper and further development and detailing of interactions between domains can be applied in future analyses (adding e.g. social ecosystem functions, power relations etc.). More important though, these analyses may serve as inputs to learning of tourists and guides and thus serve an ecotourism purpose.

One of the important inputs for learning in an ecotourism setting is that complex relations between society, nature, and technology are not stable but are consistently developing over time. Our case area analyses shows that different SETs domains have dominated during the four phases: the ecological-biophysical domain dominated during the pre-disruption phase but social and technological pressures gradually increased and in the disruption phase the technological-infrastructure domain dominated, which almost eradicated the ecologicalbiophysical domain and paid limited attention to the social-behavioral domain. During the military phase the technological-infrastructure domain remained strong but the ecologicalbiophysical domain slowly recovered through the rewilding of the site. Interests from the 
social-behavioral domain increased to the extent that it became predominant during the present day recreational phase along with a strong ecological-biophysical domain inside the park. In the transition from military phase to recreational phase a number of fringe areas were used for urbanization, freeways, metro lines and hereby intensified the technologicalinfrastructure domain outside the park. Inside the park, the technological-infrastructure domain is still present in e.g. regulating the water table but plays a discrete role. It may however gain more attention in the upcoming plans for climate change adaptation which have already resulted in the construction of higher dikes.

Our current R\&D project deliberately use the narrative of Nature Park Amager to condense the former told story as 'the man-made land' (Norrøn Architects, 2017), also reflected in proposing new facilities (e.g. a museum formed as a stairway illustrating rising sea levels in a 'climate change barometer'), and recreational facilities on the missile launches. Along with our development of guided ecotourism tours, it may increase the awareness of the massive human influences on what appears to be a nature area. This illustrates the era of the Anthropocene in a way that not only supports narratives of human ecosystem destruction, but also highlights a process with positive, unintended impacts. These impacts may be revealed in guided field trips for school children etc. The dynamic interactions between humans and more-than-human nature are clearly evident in such rewilded areas, as visitors are confronted with so-called hybridized nature in urban fringe areas where socio-ecological relations and interactions are more obvious than in pristine natural areas (Cronon, 1995).

These transitions toward a rewilded landscape relate also to shifting nature perceptions over time (Mace 2014), from "nature for itself", "nature despite people", to "nature for people", and are therefore relevant for ecotourists in terms of relativizing conservation and socioecological learning. More recently (2010s), the focus has shifted towards a more two-way, dynamic interrelationships between "people and nature" with emphasis on the importance of cultural structures and institutions for developing sustainable and resilient interactions between human societies and the natural environment (Mace 2014). We believe the UN Sustainable Development Goals reflect this change in perceptions. However, the historical shifts in focus have resulted in a pluralism of views and motives on conservation, which can be mutually supportive but differences in underlying ideologies can also cause frictions and tensions (Mace 2014). Again, even conflicts are helpful in educating the traveler.

The rewilding processes on site have been massive and relatively undisturbed. The conversions of sea to land and changes in salinity and groundwater level have resulted in 'novel' ecosystems differing from the 'ancient' nature (Mace 2014). While marine ecosystems and species have been lost, the new freshwater lake and drainage channels have added new ecosystems to the site and biodiversity is high with over 500 different species present including over 280 plant species, 159 insect species, 52 bird species some rare species of butterflies and orchids (Michaelsen, Bak, Andersen, 2013). Local citizens and environmental activists have recently demonstrated the intrinsic and relational values of these novel ecosystems in large and disruptive protests over the threat of building plans on the Easter fringe of the Amager Commons. These interactions indicate that rewilded nature can result in 'novel' ecosystems of high socio-ecological quality that may serve as a foundation for Urban Ecotourism. The rewilded area fulfills the key ecotourism criteria of being naturebased, sustainable ecosystems and providing interpretation and education. The site offers excellent opportunities for educating both local people and tourists on the man-made influences on nature and related consequences (e.g. the rising sea level and need for climate mitigation and adaptation) but also on the positive side on recovery and the strong forces of rewilding nature from a state of high disruption. 
These complex relations between society, nature, and technology at Nature Park Amager underlie the interdependence of conservation, community, and ecosystems - a gift for learning in urban eco-tourism; unfolded and maintained it may be a part of a broader sustainable tourism development. Looking at it from this perspective, a niche development in urban ecotourism as in Nature Park Amager provides a path in sustainable transition for the urban- and nature tourism markets in general, as the urban ecotourism activities enhance learning near to urban everyday living, and minimize the physical and social impacts on a site. For example, people in Greater Copenhagen can enjoy a unique and authentic nature experience of this 'novel' ecosystem accessible by bicycle or public transportation from their front door, much less carbon-intensive than an ecotourism experience of 'ancient' ecosystems in e.g. Costa Rica. Interpretation and educational perspectives on nature are not limited to the few, remote, protected nature areas but can also be linked to the processes and dynamics of rewilding within urban protected nature areas. These areas provide great opportunities for interpreting important aspects of human-nature interactions and interdependencies to both local residents and tourists. (TIES 2015). Additionally, urban ecotourism has the potential to provide direct financial benefits for conservation by generating financial benefits for both local people and private industry. Denmark is currently marketing itself as a "State of Green" (see https://stateofgreen.com/en/) attracting business tourists to the country and the capital to learn about sustainable transitions, e.g. urban planning with clean and green technologies. The offered guided tours herein deliver memorable interpretative experiences to visitors that help raise sensitivity to Copenhagen's and Denmark's political, environmental, and social perspectives. In this sense urban ecotourism can build on trends of urban rewilding to provide low-impact facilities supported and stewarded in partnership with local communities. Urban ecotourism is uniquely positioned to facilitate unique, environmentally sustainable experiences for visitors that empower both the tourist and the community.

Urban ecotourism may thus emerge as a new niche that embarks on the predominant regimes of tourism, used as a new way to 'educate the traveler' within the city limits. This adds to the 'traditional' ecotourism by bringing it from far remote places into the urban context using rewilded areas as a stepping stone. It brings forward the perceptions of nature and people having to find more harmonious ways of coexisting and learning in a time of global warming, rising sea levels and other threats. The current regime of tourism and the regime of urban planning will have to adjust to this niche in new narratives, infrastructures, planning approaches, and in new ecosystemic valuations in i.e. environmental impact assessments. The socio-ecological-technological history of urban blue-green areas is a fine opportunity as a stepping-stone.

\section{Conclusions}

The transition of the Nature Park Amager reflects in a small scale a wide range of social, technological and ecological transformations that have taken place particularly within the past century and even before. Different SETs domains have dominated during the four phases: the ecological-biophysical domain dominated during the pre-disruption phase, the technologicalinfrastructure domain during the disruption phase and military phase and the social-behavioral domain now leading the recreational phase but strong supported by the ecological-biophysical domain and more discrete influences from the technological-infrastructure domain.

Our site analyses of Nature Park Amager illustrate how an area a few kilometers from the city center of Copenhagen, Denmark has been transformed over time: From 'ancient' nature area to 'novel' nature; from seafloor to dry land, from urban fringe to being centrally located within the urban fabric, from wasteland to protected nature area and designated Nature Park, from a place of avoidance to an attractive recreation site with nature interpretation. This 
historical background has served the platform for a niche formation by transition management, since 2018 in urban ecotourism; a development involving various tourism trades, municipalities, researchers, with new interpretation tours on offer to tourists. All described transitions reflect significant social, technological, and ecological changes in modern societies during the past centuries and different perceptions of these over time.

Rewilding has played a major role in these transitions after the disruption and created not only new ecologies but also recreational attractiveness that may even provide opportunities for further development of urban ecotourism.

Urban ecotourism may be a new approach/route to establishing a better understanding of our role in shaping and transforming our environment and the consequences (era of the Antroprocene). Furthermore, rewilding and increased education/interpretation can illustrate this and how we can repair and reestablish ecosystems.

\section{References}

Andersson , E.; Barthel, S.; Borgström, S.; Colding, J.; Elmqvist, T.; Folke, C.; Gren, A..(2014). Reconnecting Cities to the Biosphere: Stewardship of Green Infrastructure and Urban Ecosystem Services. AMBIO 2014, 43,445-453

Berger, A. (2006) 'Drosscape in the landscape', in C. Waldheim (ed) The urbanism reader, Princeton, NJ: Princeton University Press, pp 197-217.

Biomedia (2013) Vidensindsamling Natur 2013, Amager Fælled. Biomedia for Københavns Kommune. (In Danish)

Braun, B. 2002: The intemperate rainforest: nature, culture and power on Canada's west coast. Minneapolis: University of Minnesota Press.

Caspersen, O. H.(2018): Naturpark Amager. In: Glemmer du. Tårnby Kommunes lokalhistoriske tidsskrift 3.27 p. Tårnby Kommune. (in Danish)

Caspersen O. H.,(2016): Kalvebodkilen. In: Chistiansen, C. (eds): Den grønne metropol. 555588 HOKA. (in Danish)

Caspersen O. H, Petersen R, M. (2015): Naturpark Amager. Muligheder og indsatser temarapporter. 2015, Inst. For Geovidenskab og Naturforvaltning. Københavns Universitet. 204 pp. (in Danish)

Cronon, W., (1995): Uncommon Ground: Rethinking the Human Place in Nature, New York: W. W. Norton \& Co.

De Schutter, O., Lenoble, J. (Eds.), 2010. Reflexive Governance: Redefining the Public Interest in a Pluralistic World. Oxford: Hart

Depietri, Y., McPhearson, T., Bonn, A., Kabisch, N., Korn, H., \& Stadler, J. (2017). Integrating the Grey, Green, and Blue in Cities: Nature-Based Solutions for Climate Change Adaptation and Risk Reduction. Theory and Practice of Urban Sustainability Transitions, 91-109. doi: 10.1007/978-3-319-56091-5_6.

Donlan, J. (2005). Rewilding North America. Nature. 436 (18), pp. 913-914

Ebbesen, E. R.\& Holm, J. (2018): Literature review on Urban Ecotourism. INUT working Paper 3, Roskilde University.

Fennell, D. A. (2015, fourth edition) Ecotourism. Routledge

Forsvarsministeriet og Miljøministeriet (1974) Forsvarets arealer-en beretning fra forsvarministeriets naturfredningsudvalg. $138 \mathrm{pp}$. (In Danish)

Friluftsrådet (1990) Vestamager - En kort gennemgang af historie, biologi og fremtid. 41 pp. (In Danish) 
Geels, F. (2011): The role of cities in technological transitions. Analytic clarifitions and historical examples. In: Bulkeley, H., Broto, V.C., Hodson, M. \& Marvin,S. . (eds.): Cities and low Carbon Transitions, Routledge.

Geodatastyrelsen (1920) Lave målebordsblade 1920.

Geodatastyrelsen (2014) Kort 100.

Gibson, A., Dodds, R., Joppe, M., \& Jamieson, B. (2003). Ecotourism in the city? Toronto's Green Tourism Association. International Journal of Contemporary Hospitality Management, 15(6), 324-327

Gulsrud, N. M., Raymond, C.M., Rutt, R. L., Olafsson, A. S., Plieninger, T., Sandberg, M., Beerye, T. H. \&, Jönsson,I.(2018) 'Rage against the machine'? The opportunities and risks concerning the automation of urban green infrastructure. Landscape and Urban Planning, Volume 180, December 2018, Pages 85-92.

Gunn, S. \& Owens, A. (2006). Nature, technology and the modern city: an introduction. Cultural Geographies, 13 (4), 491-496.

Hall, C. M. (2013) The ecological and environmental significance of urban wastelands and drosscapes, in Campos, M. J. Z.\& Hall,M : Organising waste in the city, Policy Press.

Higham, J., \& Lück, M. (2002). Urban Ecotourism: A Contradiction in Terms? Journal of Ecotourism, 1(1), 36-51.

Hodson, M. \& Marvin, S. (2010): Can cities shape socio-technical transitions and how would we know if they were? In: Research Policy, vol. 39, pp. 477-485.

Holden, A. (2015): Evolving perspectives on tourism's interaction with nature during the last 40 years, in: Tourism Recreation Research, Vol. 40, No. 2, 133-143

Holm, J. \&Kaae, B.C. (2017): Definitionsramme for Byncer økoturisme https://rucforsk.ruc.dk/ws/files/61040362/RAMME FOR INUT PROJEKTET IFT By.pdf (In Danish)

Holm, J., Pedersen, L.M.P. \& Sørensen, S. (2013): Experiencing organic farms and food by regional tourism innovation, in: Acta Agriculturae Scandinavica, Section B - Soil \& Plant Science, Volume 63, Supplement 1 Special Issue: Local Food - a step towards better and more environmentally friendly products

Jegdić, V. \& Gradinac, O., (2016). Cities as Destinations of Urban Ecotourism: The Case Study of Novi Sad. Acta Economica Et Turistica, 2(2).

Kaika, M. (2005). City of flows. Modernity, nature, and the city. New York, NY: Routledge.

Kowarik, I. (2005) 'Wild urban woodlands: Toward a conceptual framework', in Kowarik, I.\& Körner, S. (eds). Wild urban woodlands, Berlin: Springer, pp 1-32.

Kowarik, I. (2013): Cities and Wilderness- a new perspective. In: International Journal of Wilderness .Volume 19, Number 3.

Kowarik, I. (2018): Urban wilderness: Supply, demand, and access, in: Urban Forestry \& Urban Greening, 29

Kowarik, I.(2019). The "Green Belt Berlin": Establishing a greenway where the Berlin Wall once stood by integrating ecological, social and cultural approaches. Landscape and urban planning, Vol. 184, 2019-04, p. 12-22

Lee, J. \& Lee, D., (2015). Nature Experience, Recreation Activity and Health Benefits of Visitors in Mountain and Urban Forests in Vienna, Zurich and Freiburg. Journal of Mountain Science 12(6)., 12(2), 1551-1562.

Lewis, S.L. \& Maslin, M. (2015). Defining the Anthropocene. Nature, 519(7542), pp.171180.

Liua, Y. \& Pan, X. (2014). Ecotope-based Urban Post-industrial Landscape Design. IERI Procedia 9, p. 185 - 189. https://www.sciencedirect.com/science/article/pii/S2212667814001087

Mace, G. M. (2014) Whose conservation? Science, Vol. 345, Issue 6204, pp. 1558-1560.Link: http://science.sciencemag.org/content/345/6204/1558.full 
Maćkiewicz, B. \& Konecka-Szydłowska B. (2017) Green Tourism: Attractions and Initiatives of Polish Cittaslow Cities. In: Bellini N., Pasquinelli C. (eds) Tourism in the City. Springer

Margaryan, L. (2012): “Rewilding” and Tourism: Analysis of an Optimistic Discourse on Nature Conservation. Master Thesis, Wageningen University and Research Center McPhearson, T., Pickett, S. T. A., Grimm, N. B., Niemelä, J., Alberti, M., Elmqvist, T.,\& ... Qureshi, S. (2016). Advancing Urban Ecology toward a Science of Cities. BioScience, 66(3), 198-212.

Mell, Ian (2016): Global Green Infrastructure: Lessons for successful policy-making, investment and management, Routledge

Mellemgaard, S. (2001): Kroppens natur-sundhedsoplysning og naturidealer $i 250$ år. Museum Tusculanums forlag. (In Danish)

Michaelsen, A. N., Bak, J. \& Andersen, L. 2013. Vidensindsamling Natur 2013, Amager Fælled. Biomedia for Københavns Kommune.(in Danish)

Naturstyrelsen (2014): Amager Naturpark - Naturparkplan 2015-2020. Naturstyrelsen Hovedstaden, Tårnby Kommune, Dragør Kommune og By \& Havn - in cooperation with Planværkstedet ApS. 52 p. (In Danish)

Norrøn Architects (2017) The Manmade Land, Nature Park Amager, handout

Park, J. \& Kim, Y.(2019): Economic impacts of a linear urban park on local businesses: The Case of Gyeongui Line Forest Park in Seoul. Landscape and Urban Planning Volume 181, January 2019, Pp. 139-147

Petersen, R. M. \& Caspersen, O. H. (2015): Naturpark Amager. Muligheder og indsatser Katalog. Inst. For Geovidenskab og Naturforvaltning. Københavns Universitet. 63 p. (in Danish)

Rotmans, J., Loorbach, D., 2009. Complexity and transition management. Journal of Industrial Ecology 13(2), 184-196.

Sarlat, E. M., García, O., \& Wood, P. (2013). Urban ethno-botanists, storytellers of our cities: an ecotourism initiative from Barcelona, Spain. Journal of Ecotourism, 12, 3, 189-196

Schot, J., Geels, F. W., 2008. Strategic niche management and sustainable innovation journeys: theory, findings, research agenda, and policy. Technology Analysis \& Strategic Management 20(5), 537-554.

Smith, A., \& Stirling, A. (2010). The Politics of Social-ecological Resilience and Sustainable Socio- technical Transitions. Ecology and Society, 15(1), 11.

Stoetzer, B. (2018). Ruderal Ecologies: Rethinking Nature, Migration, and the Urban Landscape in Berlin. Cultural Anthropology. Issue 33.2. https://culanth.org/articles/956-ruderal-ecologies-rethinking-nature-migration

Søndergaard, B., Holm, J. \& Stauning, I. (2015) Chapter 2: Transition Theory - Sustainable Transition of Socio-Technical Systems. In: Holm, J., Jensen, J.O. Stauning, I. \&Søndergaard, B. (eds.): Sustainable Transition of Housing and Construction, Frydenlund Academic.

The Freshkills Park Alliance (2018) Freshkills Park. Link: https://freshkillspark.org/

The International Ecotourism Society [TIES] (2017) What is Ecotourism? http://www.ecotourism.org/what-is-ecotourism

Timur, S. \& Getz, D. (2009). Sustainable Tourism Development: How Do Destination Stakeholders Perceive Sustainable Urban Tourism? Sustainable Development 17 (4): 220-32.

UNWTO (2016): Tourism and the SDGs. http://icr.unwto.org/content/tourism-and-sdgs (approached 03.07.2018) 


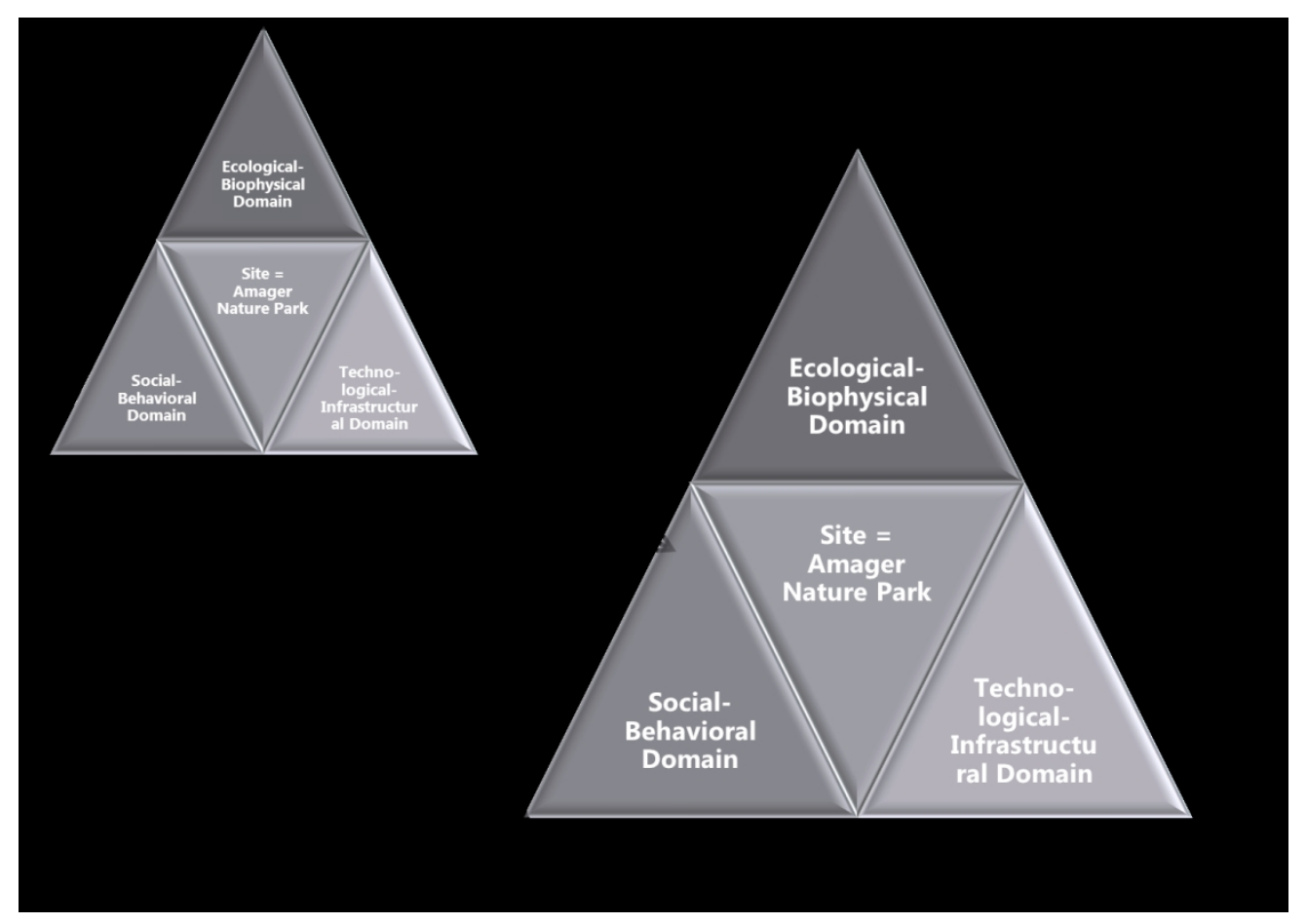

Figure 1

$253 \times 178 \mathrm{~mm}(150 \times 150 \mathrm{DPI})$ 


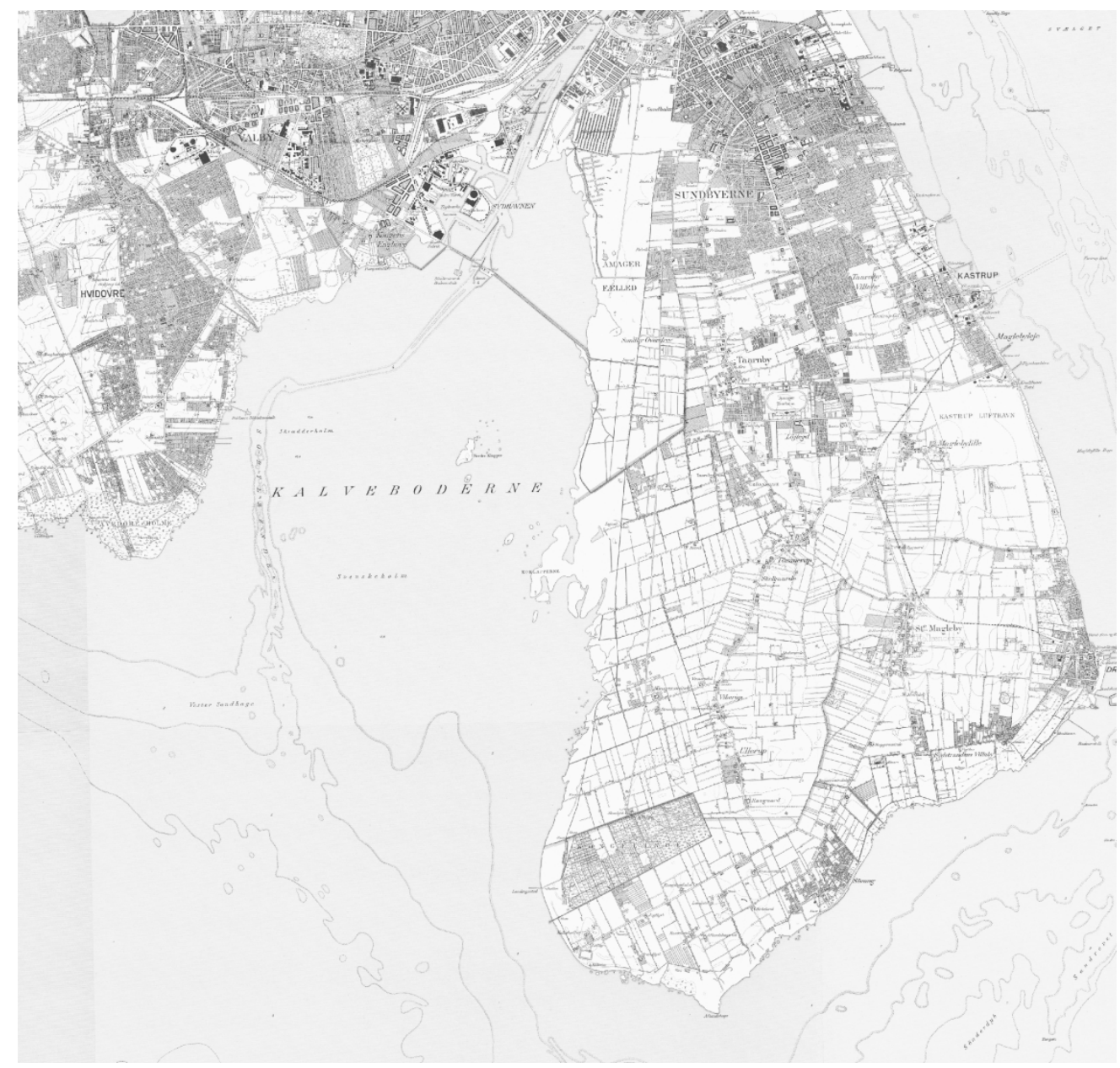

Figure $2 \mathrm{a}$

$237 \times 226 \mathrm{~mm}(300 \times 300$ DPI $)$ 


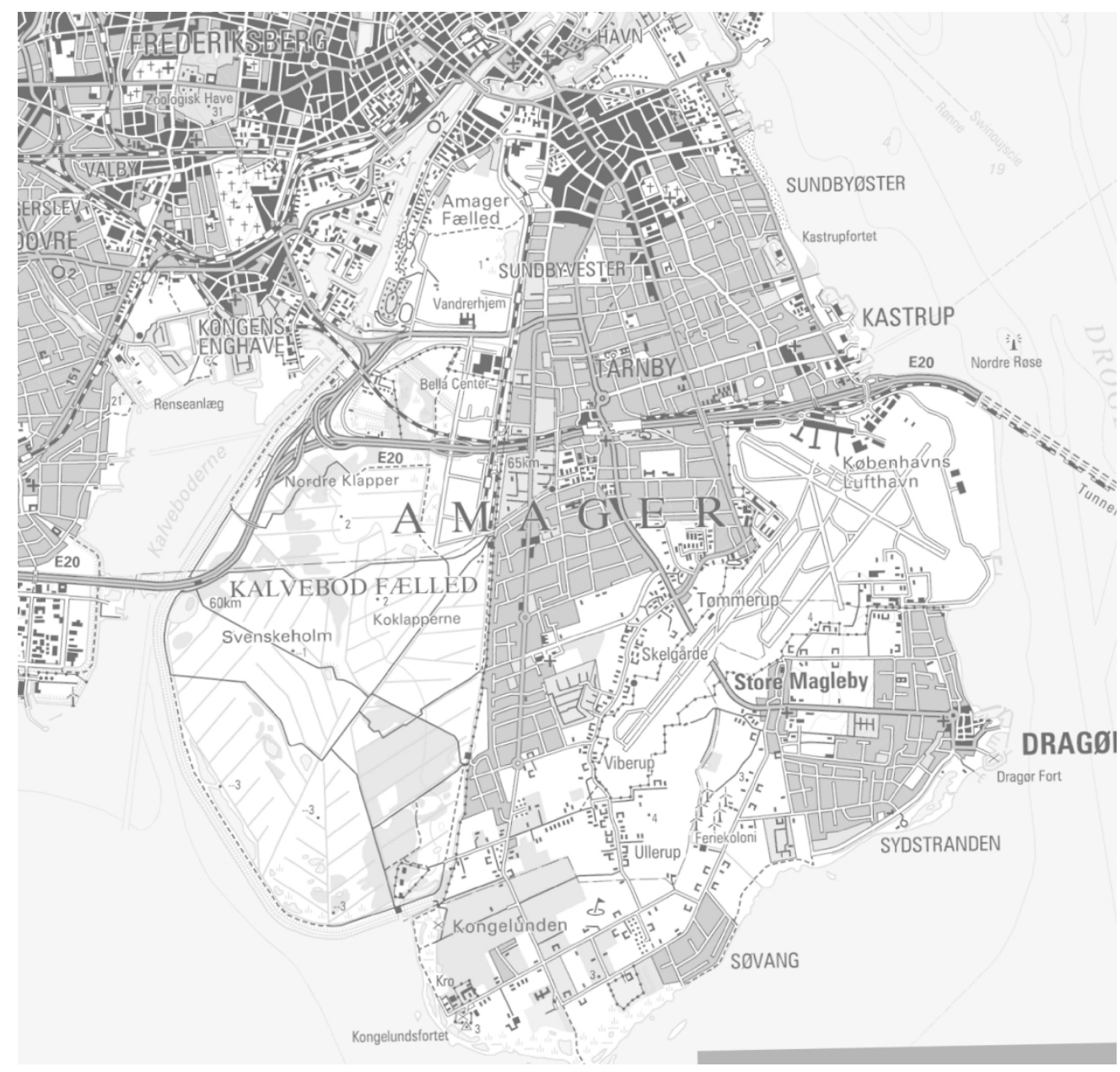

Figure $2 b$

$237 \times 226 \mathrm{~mm}(300 \times 300 \mathrm{DPI})$ 
Nature enacted in culture, politics and regulation in DK - Amager nature area through time

\begin{tabular}{|c|c|c|c|c|}
\hline Phase & $\begin{array}{l}\text { I (1600-1938) } \\
\text { Pre-disruption }\end{array}$ & $\begin{array}{l}\text { II (1939-56) } \\
\text { Disruption }\end{array}$ & $\begin{array}{l}\text { III (1956-1984) } \\
\text { Military phase }\end{array}$ & $\begin{array}{l}\text { IV (1984-present) } \\
\text { Recreational phase }\end{array}$ \\
\hline \multicolumn{5}{|c|}{ Ecological-biophysical domain } \\
\hline Ecosystem types & $\begin{array}{l}\text { Shallow sea, coastal marshlands, } \\
\text { coastal meadow, higher parts } \\
\text { used for grazing }\end{array}$ & $\begin{array}{l}\text { Almost total } \\
\text { habitat loss in land } \\
\text { and sea areas of } \\
\text { site }\end{array}$ & $\begin{array}{l}\text { Slow desalination and colonising } \\
\text { species on dry seafloor, drainage of } \\
\text { coastal marchlands, Freshwater and } \\
\text { saltmeadows, lake, grasslands, }\end{array}$ & $\begin{array}{l}\text { Freshwater and salt meadows, lake, grasslands, } \\
\text { forestation on dryer parts (mainly Birch and Willow) }\end{array}$ \\
\hline Species richness & $\begin{array}{l}\text { High species richness on land } \\
\text { and in sea }\end{array}$ & Very low & Slow increase in terrestrial species & $\begin{array}{l}\text { Increasing species richness \& rare species, grazing adds } \\
\text { to diversification of species. Some invasive species. } \\
\text { Deer introduced } 1980 \mathrm{~s}\end{array}$ \\
\hline $\begin{array}{l}\text { Urban nature type } \\
\text { (Kowick) }\end{array}$ & Ancient & Disruption & $\begin{array}{l}\text { Novel } \\
\text { (rewilding) }\end{array}$ & $\begin{array}{l}\text { Novel } \\
\text { (rewilding continues) }\end{array}$ \\
\hline $\begin{array}{l}\text { Conservation framing } \\
\text { (Mace) Nature perception }\end{array}$ & $\begin{array}{l}\text { Nature for itself (Mace) } \\
\text { Utilitarian }\end{array}$ & $\begin{array}{l}\text { Nature for itself } \\
\text { (Mace) Utilitarian }\end{array}$ & $\begin{array}{l}\text { Nature for itself (Mace) } \\
\quad \rightarrow \text { Nature despite people }\end{array}$ & $\begin{array}{l}\text { Nature for people (Mace) } \\
\quad \rightarrow \text { People and nature (Mace) }\end{array}$ \\
\hline \multicolumn{5}{|c|}{ Technological-infrastructural domain } \\
\hline $\begin{array}{l}\text { Technology and } \\
\text { Infrastructure }\end{array}$ & $\begin{array}{l}\text { Shooting range inner common } \\
(1600) \\
\text { Military battery (1770) } \\
\text { Afforestation of } \\
\text { Kongelunden }(1818) \\
\text { Proposals for coastal } \\
\text { containment }(1872+1892+ \\
\text { 1934) } \\
\text { Military facilities (1916) } \\
\end{array}$ & $\begin{array}{l}\text { Dikes constructed } \\
\text { and pumping } \\
\text { stations, } 3000 \text { ha. } \\
\text { sea converted to } \\
\text { land (1939-1942) } \\
\text { Drainage channels } \\
\text { roads \& facilities } \\
\text { (1956). Pumping } \\
\text { keeps land dry } \\
\end{array}$ & $\begin{array}{l}\text { Military activities and facilities } \\
\text { increase from } 1956 \\
\text { Missile launches } 1959 \text { to } 1981 \\
\text { Military technology outgrows site } \\
\text { Area abandoned by military (1984). } \\
\text { Dump of Copenhagen (1956-74) } \\
\text { incl. chemical industrial waste. } \\
\text { Housing development starts (1965) } \\
2500 \text { units built (plan: } 25.000 \text { units) } \\
\end{array}$ & $\begin{array}{l}\text { Urbanisation of fringes of site (Ørestad m.m.) } \\
\text { Traffic infra-structure: freeway and bridge to Sweden } \\
(2000) \text {, Metro (2002) } \\
\text { Groundwater regulated through pumping stations - } \\
\text { level increased } \\
\text { Existing on-site roads used for recreation from } 1984 \text {. } \\
\text { Demining completed (1990) Dikes increased } 2 \mathrm{~m} \text {, } \\
\text { climate change adaptation (2005-2009) }\end{array}$ \\
\hline \multicolumn{5}{|c|}{ Social-behavioral domain } \\
\hline Land use on site & $\begin{array}{l}\text { Some fishing in marine part } \\
\text { Commons and meadows used } \\
\text { for grazing } \\
\text { Norther part becomes landfill } \\
\text { for waste from Copenhagen \& } \\
\text { site for public executions } \\
\text { Some military uses emerge }\end{array}$ & $\begin{array}{l}\text { Construction site } \\
\text { for coastal } \\
\text { containment } \\
\text { employing } 600 \\
\text { people }\end{array}$ & $\begin{array}{l}\text { Military shooting range (no public } \\
\text { access). } \\
\text { Bird area in southern part } \\
\text { Municipal dump }\end{array}$ & $\begin{array}{l}\text { Grazing reintroduced } 1984 \\
\text { Recreational area with public access to main roads } \\
\text { (1984). Access to more areas after demining (1990) } \\
\text { More trails, entrances, visitor facilities, nature inter- } \\
\text { pretation and educational programs } \\
\text { Designated as Nature Park 2015, } \\
\text { Large funding of visitor facilities (2016->), }\end{array}$ \\
\hline
\end{tabular}




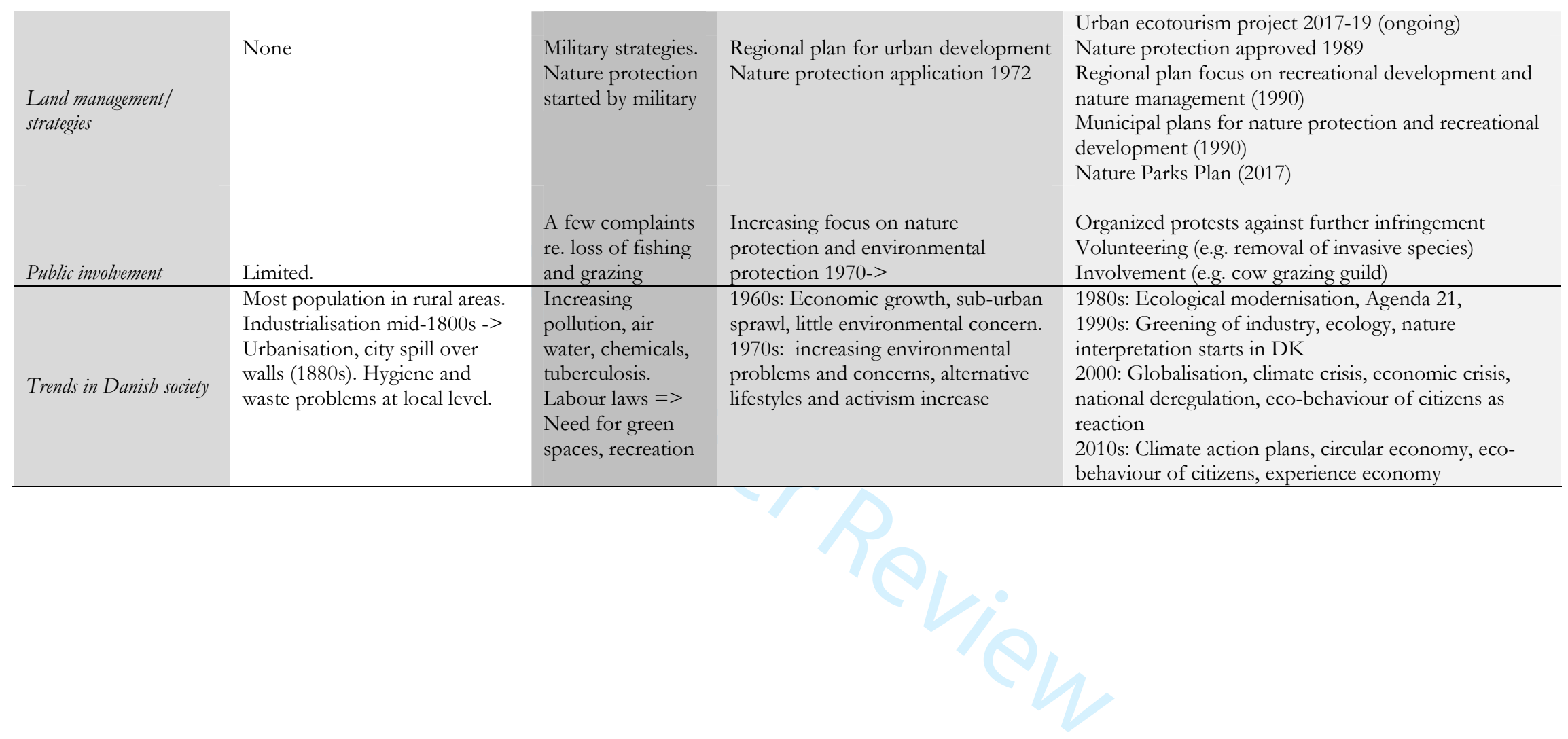

